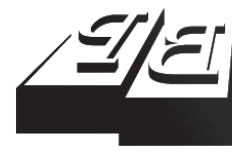

\section{BUSINESS PERSPECTIVES}

()

LLC "CPC "Business Perspectives" Hryhorii Skovoroda lane, 10 Sumy, 40022, Ukraine www.businessperspectives.org

Received on: $24^{\text {th }}$ of November, 2019 Accepted on: $17^{\text {th }}$ of February, 2020 Published on: $2^{\text {nd }}$ of March, 2020

() Bogdan V. Derevyanko, Vitaliy M. Pashkov, Olha A. Turkot, Nadiia V. Zahrisheva, Olena S. Bisiuk, 2020

Bogdan V. Derevyanko, Doctor of Law, Professor, Faculty of Law, Department of Economic Law, Donetsk Law Institute of the Ministry of Internal Affairs of Ukraine, Ukraine. (Corresponding author)

Vitaliy M. Pashkov, Doctor of Law, Professor, Faculty of Law, Department of Civil, Commercial and Financial Law, Poltava Law Institute of Yaroslav Mudryi National Law University, Ukraine.

Olha A. Turkot, Ph.D. in Law, Faculty of Law, Department of Economic Law, Lviv State University of Internal Affairs, Ukraine.

Nadiia V. Zahrisheva, Ph.D. in Law, Faculty of Business Administration and Law, Department of Law, Kyiv University of Market Relations, Ukraine.

Olena S. Bisiuk, Ph.D. in Law, Faculty of Law, Department of Public Law Disciplines, Kyiv International University, Ukraine.

Bogdan V. Derevyanko (Ukraine), Vitaliy M. Pashkov (Ukraine),

Olha A. Turkot (Ukraine), Nadiia V. Zahrisheva (Ukraine), Olena S. Bisiuk (Ukraine)

\title{
ADDRESSING THE ISSUE OF CORPORATE RAIDING IN UKRAINE
}

\begin{abstract}
The phenomenon of "raiding," i.e., the unlawful establishment of control over the property or governing boards of an enterprise, as well as the seizure of its shares, has been reported in all countries of the world for many decades. This phenomenon has the most dangerous forms in the states with the underdeveloped economy and legal system, particularly in Ukraine. The paper aims to determine the areas for counteracting and overcoming corporate raiding in Ukraine and to provide proposals for improving the legislative framework for reliable protection against attacks on the enterprises' property.

The information in the paper, including the geography of raider attacks, indicates a greater vulnerability of enterprises in the most economically developed regions, with extensive transport infrastructure and the prospects for various industries and sectors of the economy development. The state should take some steps to increase the level of enterprises protection against raider attacks. Thus, to improve the quality of preventing and combating corporate raiding, this paper argues the need to develop and adopt the Corporate Property Protection Code of Ukraine. The introduction of the raider attacks register will be an effective measure to warn potential investors and counterparties about the dangers of cooperation with certain companies. The state register should be bilingual (Ukrainian and English) and contain information on the attempts and cases of raider attacks on property and corporate business rights. Also for further innovations in starting a business, Ukraine must pay attention to New Zealand's and Finland's experience.
\end{abstract}

\section{Keywords}

\section{JEL Classification}

\section{INTRODUCTION}

Almost every country faces the situations with attacks on the property of business entities. Such attacks are called corporate raiding. In some countries, these attacks are clearly defined at the legislative level, while they are not fully defined at others. In terms of legal regulation of raider attacks, the legislation protects the legal rights and interests of both the owners of corporate property and participants (shareholders) who can independently decide how to proceed. It is worth paying attention to the fact that in the majority of the developed countries, raiders at tack those enterprises that work inappropriately, i.e., they do not generate income sufficient to ensure continued functioning. In developed states, raider attacks usually have certain borders or "red lines," and raiders usually adhere to them. States with a developing economy and a legal system that is only being formed most often lack the legislative limits for raider attacks, and the vast majority of participants in economic relations do not have legal and any other culture. In Ukraine, legislation regarding the regulation of raider attacks and their translation into the legal field is being developed. In particular, attempts are being made to adopt a significant number of regulations aimed at enhancing protection against attacks on property and governing boards of business entities. 
Raider attacks exist in each country, but the methods and modalities of these attacks are different. The system of protection against attacks on the property of business entities is also different, particularly in terms of the effectiveness of state protection and state support for honest businesspersons. Ukraine is only trying to build a system of effective legislation and economic practice to protect legitimate businesses from raider attacks.

In many countries, raiders function as "orderlies," i.e., those who help ineffective entities to continue their business by buying shares/property of the enterprise, thereby changing their management. Often the raiders improve the system of work. However, there has been a negative trend in Ukraine regarding raider attacks. The objects of such attacks are exclusively those companies that are competitive in the market, have achieved significant profits, and continue to develop their activities by creating new branches and introducing new technologies. In particular, attacks on the property of agricultural enterprises and business entities that carry out activities in the field of IT services have become frequent in recent years. This situation is unacceptable and requires finding ways to prevent and combat raider attacks. In conjunction with the study of the ways and methods of raider attacks in different countries, as well as the system of protection against them, it is possible to gain useful experience and improve the legislation in their country, which will be aimed at effective counteraction and protection against raider attacks on the property of enterprises.

In this regard, the above topic is relevant for study and analysis of the situation with raider attacks in Ukraine and countering them.

\section{THEORETICAL BASIS}

A significant number of scientists worldwide study the topic of corporate raiding and counteract this negative phenomenon to increase the security level and effectiveness of mergers and acquisitions of companies and the sale of shares and property of enterprises.

Kireev (2007) notes that at the beginning of the 21st century, the corporate control market faced a new phenomenon: the appearance of different groups that wanted to begin systematic control over assets of other economic actors. Paul (2007) analyzes the role of corporate boards in considerable decline in share value after the purchase announcement. The results of the analysis show that it is less likely to complete value-decreasing bids in companies, which have an independent board, assuming that boards influence the corporate responses to information in stock prices. Köke (2002) analyzes the deciding factor of acquisition and failure for a huge amount of German corporations, separately for public and private corporations. Both of these corporations are more likely to gain or to fail when company is small, leverage is high, performance is poor.

Rochlitz (2014) analyzes the data, including 312 incidents of illegal corporate raiding in the peri- od between 1999 and 2010. His work identifies the change in the regional and sectoral division of raids over time and the increasing participation of state authorities in raider attacks in Russia. Based on the evidence from different regions of Russia, Rochlitz (2017) finds that the result depends on the type of violence. These conclusions are similar to the theory where companies search the protection of the formal economy against physical violence in regions with decentralized predation but hide in the informal economy against predatory state officials and corporate raiders in regions where predation is centralized. Vasyliev and Nimkovych (2016) point out that the right to purchase newly issued shares is an element of protection of shareholders from the dilution of a portfolio of shares in the process of a new issue. The priority of the "old" shareholders over the "new" ones is aimed both at preserving the relative share in the capital of the joint-stock company and serves as an element of anti-raider protection. Novak and Zatvarskyi (2017) classify and investigates "white," "gray," and "black" raiding and its main factors in Ukraine. Exploring the main ways to protect against unfriendly takeovers, he distinguishes between preventive and prompt methods. Shevchuk (2017) examines the list of features of businesses that can make them attractive targets for raider attacks, the main ways they are attacked, and how to counter these attacks. Deutsch, Keil, and Laamanen (2007) examine how the remu- 
neration paid for outside directors affects the acquisition behavior of the company. Applying panel data of Standard \& Poor's 1500 firms in the period between 1996 and 2002, the authors concluded that stock and stock option pay for outside directors are related in an inverted U-shaped manner to a firm's acquisition rate and that for stock options, this relationship is moderated by board composition. Parnes (2009) considers an unrepeatable motive for corporate acquisitions among troubled companies: willingness to increase the creditworthiness.

Andrushkiv and Maliuta (2016) investigate the economic and property security of businesses, the social and legal prerequisites for raiding, ways to carry out raiding and formulation of a protection strategy, preventing the capture and takeover of raiders. Vashkiv (2016) explores the mechanism of raiding and its spread in the national economy. Demers, Giroux, and Chreim (2003) investigate the methods of top managers how to legitimize change in official announcements. It focuses on the foundations of legitimacy invoked using both Weber's typology, based on modes of authority, and the conventionalist model, stressing the constitutive frameworks that justify collective action.

Vasylenko (2017) notes that the involvement of law enforcement agencies and judges is an integral part of an unfriendly takeover of a business. Milyavskyi and Korobka (2016) point to the negative impact of raiding on the perception of Ukraine abroad. Yastrubetska (2017) explores the main stages of a raider takeover and the factors that a raider analyzes before taking over a company.

Lin, Officer, and Zou (2011) study the effect of liability insurance of directors and officers (D\&O insurance) on the results of merger and acquisition $(M \& A)$ decisions. The evidence supports the theory that the provision of $\mathrm{D} \& \mathrm{O}$ insurance can prompt unintended moral hazard by shielding the directors and officers from the discipline of shareholder litigation (Lin, Officer, \& Zou, 2011). Mokiy, Fleychuk, and Datsko (2016) identify the root causes of raiding and the main mechanisms for improving the institutional environment.

These and other researchers offer various ways and mechanisms to improve the procedures for the purchase and sale of shares and property of companies, to combat corporate law violations and attacks on the legitimate activities of all parties to economic relations. However, a significant number of legal relationships related to the protection of economic entities (primarily joint-stock companies) remain outside the scope of attention of researchers and, therefore, require additional scientific exploration.

Corporate raiding is recognized as the main problem to post-Communist economic and political modernization and recently has been more widely available in Ukraine from those in any other identically large and advanced economy (Rojansky, 2014). Corporate raiding - is the stunning thing under which criminals, business rivals, and even state officials visit business offices and force owners or staff to transfer business assets, land, or property (Osipian, 2018).

For more than twenty years, Ukraine has been taking steps to counteract the raider attacks on the property of enterprises by amending the legislation and creating the appropriate agencies to protect business entities against such attacks. Reforms aimed at improving the system of registration of business entities, decentralization, etc. were also implemented in Ukraine. However, raiders continue to attack the assets of business entities, inventing new "formally legal" ways and methods. The factors facilitating the activity of raiders are the absence of legal regulation of this phenomenon and loopholes in the current legislative rules, which enable to avoid prosecution. Åslund (2014) indicates that endemic corruption influences on economics and politics in Ukraine, which is the main threat to the nation.

This study aims to identify ways to counteract and overcome raiding in Ukraine and to provide proposals for improving the legal framework for reliable protection against attacks on corporate property.

\section{RESULTS AND DISCUSSION}

In Ukraine and some countries of the world, there is a conditional classification of raider attacks: greenmail, white, gray, and black raiding. The above classification is conditional and is not le- 
gally enshrined. Official statistics include cases of control of the enterprise or the final takeover of all or large part of its property. Because of this, the scale of raiding in the country looks a bit lower than the actual number. Besides, this phenomenon is often latent because of the blackmail and intimidation of shareholders or property owners. However, statistics in Ukraine looks rather threatening. Thus, since 2014, the number of raider attacks has increased, and the number had almost doubled from 234 registered cases in 2014 to 414 cases in 2017. Most often, raider attacks are carried out in Kyiv and Kyiv region. In the last five years, 397 attacks were registered there. Dnipropetrovsk region (133) and Lviv region (104) are ranked second (Kuchuk, 2018). Unfortunately, the situation with raider attacks on enterprises and the seizure of their property does not change for the better over time. Thus, as of June 2019, Kyiv and Kyiv Region are the leaders in the number of raider attacks. Dnipropetrovsk region and Kharkiv region are ranked second. However, this does not mean that one has to accept the situation as a matter of fact and not try to correct it. It may be necessary to carry out an analysis based on geographical indicators. One of the most recent such analyses was conducted as of mid-2015 (Sorokivska, 2014). Comparing the dynamics of raider attacks in the regions of Ukraine (from January 2015 to May 2015), the largest part of the attacks was carried out in the Southeastern area, including 69 attacks over six months, which made up $34.16 \%$ of their total number in Ukraine. Comparing the cities where the raider attacks were carried out (from January 2015 to May 2015), it should be recognized that the most unfavorable situation is with companies in the Kharkiv region and part of the Luhansk region, which is under the control of the Government of Ukraine - 12 attacks, representing $17.39 \%$ by region and $5.94 \%$ of the total in Ukraine (Sorokivska, 2014).

If one compare's the dynamics of raider attacks in the regions of Ukraine (from January 2015 to May 2015), it can be noted that the least attacks were made in the Crimea - 29 attacks, which is $14.36 \%$ of the total number in Ukraine. It should be noted that the Autonomous Republic of Crimea is the so-called "gray area of law" since Ukrainian legislation does not regulate the implementation of any legal actions.
Western regions rank second among regions in terms of raider attacks. It is worth paying attention to the fact that in the Western regions, many people work abroad, and it is simply unprofitable for them to start their business at home. Currently, one of the main business areas in Ukraine is the IT industry. Accordingly, the situation can change dramatically with the ranking of raider attacks, as IT companies are one of the most productive enterprises, and the legislation that should properly protect the business in the field of IT services is being developed. The third place in the ranking in terms of raider attacks by on economic entities belongs to the Central area because Kyiv and related regions have many large enterprises that become the target of raider attacks. Instead, the Southeast area ranks fourth in terms of the number of attacks. This situation is caused by the fact that the Southeast area has the most important industrial enterprises, which are the subject of interest of raiders who may control them without much difficulty.

Comparing cities where raider attacks were made (from January 2015 to May 2015), the most favorable situation was in the economic entities in Ternopil region - only two attacks, which is 5.56\% in the region and $0.99 \%$ of the total number in Ukraine.

In the Western region, the lowest number of raider attacks was committed in the Ternopil region and Zakarpattia region due to the relatively small number of enterprises in these regions. Lviv, Chernivtsi, and Khmelnytskyi regions are next in the ranking. The situation in the mentioned areas is identical to the Ternopil and Zakarpattia regions since the mentioned areas have a small number of small enterprises. However, today the situation has changed considerably, as the sphere of IT services is developing rapidly, in particular, in the Lviv region. Ivano-Frankivsk, Volyn, and Rivne regions are next in the ranking. It is worth noting that these are the border regions whose residents work at foreign enterprises transferring their money to Ukraine or to their children who start their business here or return and start their business for the money earned. As a result, businesses are more competitive in the market, and their seizure is cost-effective for raiders. 
In the Central area and Kyiv from January to May 2015, the most favorable conditions for safe activity were in economic entities in the Sumy region and the most unfavorable in the Kyiv region. In particular, in the Sumy region, from January to May 2015, six attacks were made, which is $8.82 \%$ in the region and $2.97 \%$ of the total number in Ukraine. Most of the raider attacks on economic entities from January to May 2015 were made in the Kyiv region - 11 attacks, which is $16.18 \%$ in the region and $5.45 \%$ of the total number in Ukraine.

During the analyzed period, the least number of attacks took place in Sumy, Zhytomyr, and Poltava regions. Kirovohrad and Cherkasy regions have a developed food and light industry, mechanical engineering, ferrous and non-ferrous metallurgy, chemical and fuel industry, etc. Therefore, many businesses in these areas are the target of raider attacks. Comparing these areas with other areas of the Central region, it should be noted that perhaps the mentality of the residents is less hostile or fewer people want to commit crimes and engage in illegal business. On the other hand, the location and size of businesses may not attract raiders, which indicates the lowest incidence of attacks on enterprises in these areas of the Central region. The city of Kyiv and the Cherkasy region are in the middle of the ranking. There are many enterprises in the city of Kyiv and the Kyiv Region. The Vinnytsia region, with its significant railway junctions, is next in the ranking of the number of raider attacks. Geographically and logistically advantageous location is attractive to raiders who seize property and governing boards of enterprises in the specified area.

In the Southeastern area, from January to May 2015 , the safest conditions of activity were in the entities of the Zaporizhzhia region, and the most dangerous were in the part of the Luhansk region, which is under the control of the Government of Ukraine. In particular, during this time, seven attacks were committed in the Zaporizhzhia region, which is $10.14 \%$ in the region and $3.47 \%$ of the total number in Ukraine. From January to May 2015, 12 raider attacks were carried out in the part of the Luhansk region controlled by Ukraine, which is $17.39 \%$ in the region and $5.94 \%$ of the total number in Ukraine.
Odesa, Mykolaiv, Kherson, Zaporizhzhia and Donetsk regions have access to the sea and, accordingly, favorable location of enterprises, which explains the significant activity of raiders. However, Kharkiv region and part of the Luhansk region rank first in the number of attacks carried out in the Southeastern area. The Kharkiv region is located on the border of Ukraine. The managers of enterprises cannot protect enterprises located in part of the Luhansk region due to unstable situation and because Ukraine does not control another part of the territory of the Luhansk region and the Donetsk region.

Official data of the Prosecutor General's Office of Ukraine as of July 2018 confirm the information provided. For clarity and further analysis, they can be grouped as follows (see Table 1):

Table 1. Number of raider attacks in regions and areas of Ukraine from 2013 to 2018

\begin{tabular}{|c|c|c|c|}
\hline \multirow{2}{*}{$\begin{array}{c}\text { Rank in terms } \\
\text { of the number } \\
\text { of raider attacks }\end{array}$} & \multirow[t]{2}{*}{ Region of Ukraine } & \multicolumn{2}{|c|}{$\begin{array}{c}\text { Number } \\
\text { of raider attacks }\end{array}$} \\
\hline & & $\%$ & Number \\
\hline 1 & Kyiv and Kyiv region & 24 & 397 \\
\hline 2 & Dnipropetrovsk region & 8 & 133 \\
\hline 3 & Lviv region & 6 & 104 \\
\hline 4 & Odesa region & 6 & 97 \\
\hline 5 & Donetsk region & 5 & 81 \\
\hline 6 & Zakarpattia region & 4 & 70 \\
\hline 7 & Mykolaiv region & 4 & 60 \\
\hline 8 & Zhytomyr region & 4 & 59 \\
\hline 9 & Kharkiv region & 3 & 56 \\
\hline 10 & Kherson region & 3 & 56 \\
\hline 11 & Vinnytsia region & 3 & 56 \\
\hline 12 & Zaporizhzhia region & 3 & 52 \\
\hline 13 & Luhansk region & 3 & 47 \\
\hline 14 & Poltava region & 3 & 47 \\
\hline 15 & Rivne region & 3 & 44 \\
\hline 16 & Cherkasy region & 3 & 42 \\
\hline 17 & Kirovohrad region & 2 & 41 \\
\hline 18 & Khmelnytskyi region & 2 & 40 \\
\hline 19 & Chernivtsi region & 2 & 38 \\
\hline 20 & Ivano-Frankivsk region & 2 & 36 \\
\hline 21 & Ternopil region & 2 & 36 \\
\hline 22 & Chernihiv region & 2 & 32 \\
\hline 23 & $\begin{array}{l}\text { Autonomous Republic of } \\
\text { Crimea }\end{array}$ & 1 & 24 \\
\hline 24 & Volyn region & 1 & 22 \\
\hline 25 & Sumy region & 1 & 20 \\
\hline
\end{tabular}

The information provided, including the geography of raider attacks, indicates a greater vulnerability of 
enterprises in the most economically developed regions, with extensive transport infrastructure and the prospects for various industries and sectors of the economy development. As for the enterprises themselves, it should be noted that one of the main criteria under which the raider attacks are carried out is the efficiency of the enterprise, the prospects of the industry and its areas of activity and favorable geographical location. This situation indicates the "maturity" of raiders, their comprehensive readiness for attacks because they are first guided by the opportunity to receive income from the activities of the seized enterprises, not the ease and security of the seizure process. According to Osipian (2012), raiding in Russia is predatory, not because raiders hunt for the weakest, bankrupting, failing businesses but because they attack profitable and healthy enterprises, firms in a temporary financial crisis. With respect to the potential target of the attack, the situation does not mean that the company must work ineffectively to hide from the raider. In today's competitive environment, an enterprise can quickly transform this way. Rather, the enterprise must operate as efficiently as possible and receive maximum revenues to provide systematic versatile protection against possible threats and dangers. One of the most effective prevention measures is the organization of quality management, the establishment of a professional legal and information security service, including computer technology, cooperation with the best non-governmental security firms in the region, protection of trade secrets and economically valuable information, etc. Instead, the state should also take some steps to increase the level of protection of enterprises against raider attacks. A possible option is the development and adoption of a new regulatory enactment, such as the Corporate Property Protection Code of Ukraine (CPPCoU). It must state the scientifically sound definition of the term "raiding" and provide the mechanisms for prevention, protection, fight, documentation, and punishment of violators of the provisions of this Code. The new regulation should take into account the preliminary conclusion that raiders are most active in the most economically developed regions and industries. The most trained law enforcement officers should work in these regions.

It should be noted that the state has some positive experience in preventing and countering raiding. Thus, since November 2, 2016, a mandatory notarization of the Articles of Association and signatures of the chairperson, secretary, and participants on the minutes of the meeting was introduced when amending the constituent documents of enterprises. After that, as of March 2017, the number of raider seizures decreased by ten compared to the same period of 2016. However, shortly after the decentralization policy (which is positive), instead of two thousand state registrars, 10,000 independent registrars appeared, some of which did not mind cooperating with the raiders (which is negative). Therefore, in 2017, an anti-record was set in terms of the number of raiding seizures of property, which amounted to 414 cases. This situation is unacceptable for the economy of the state. It is worth noting that investment in the Ukrainian economy depends on the protection of the investee's investment/property. If Ukraine does not take the necessary measures to enhance the protection of property rights, then investors will find it economically unprofitable to invest in economic entities operating in Ukraine, as their property is not adequately protected against the raiders. The new Ukrainian authorities made another attempt to combat raiding in 2019. Thus, on November 2, 2019, the Law of Ukraine "On Amendments to Certain Legislative Acts of Ukraine on the Protection of Property Rights" came into force, which is intended to complicate the relations between potential raiders and dishonest notaries and state registrars (Legislation of Ukraine, 2019, October 23). However, this is only the beginning on the way to ensuring full protection of property and property rights in Ukraine.

The Property Rights Alliance calculates the International Property Rights Index (IPRI) based on three factors: the state of the legal and political environment, material property rights, and intellectual property rights. The index of protection of property rights in Ukraine in the specified ranking from 2015 to 2018 increased from 3.9 to 4.3. Even greater progress can be observed compared to 2017 when, with a score of 3.4, Ukraine ranked 123rd out of 127 countries participating in the. In 2018, according to this combined indicator, Ukraine ranked 110th among 125 member states (Property Rights Alliance, 2018), and by 2019 - 109th out of 129 participating countries. The above indicates the emergence in 2018 of a trend towards gradual improvement in the protection of material and intellectual property rights in Ukraine. However, given the results of 2019, growth is very slow. 
Table 2. Place and index of Ukraine in 2015-2019 IPRI rating

Source: Compiled by authors based on Property Rights Alliance (2019).

\begin{tabular}{c|c|c|c}
\hline No. & Year & $\begin{array}{c}\text { Index } \\
\text { of Ukraine }\end{array}$ & $\begin{array}{c}\text { Ukraine's place } \\
\text { in the overall ranking }\end{array}$ \\
\hline 1 & 2015 & 3.9 & 105 th out of 121 \\
\hline 2 & 2016 & 3.9 & 113th out of 124 \\
\hline 3 & 2017 & 3.4 & 123th out of 127 \\
\hline 4 & 2018 & 4.3 & 110th out of 125 \\
\hline 5 & 2019 & 4.433 & 109th out of 129 \\
\hline
\end{tabular}

According to the 2018 IPRI Ranking, it is necessary to monitor the countries that are in the top six and countries that are close to Ukraine in the specified ranking. In particular, Finland was ranked first out of 125 countries with an index of 8.7. The following countries were ranked next to Finland: New Zealand (8.6), Switzerland (8.6), Norway (8.5), Singapore (8.4), and Sweden (8.4). On the other side of the ranking, Cameroon and Nicaragua have the same indicators as Ukraine; Haiti occupies the last place with the indicator 2.7.

The average IPRI in the world increased only by $1.95 \%$ to 5.74 . Having improved its patent protection and access to loans, Finland swapped places with New Zealand and took the top spot. Actually, the improvement in Finland's performance in this area has also enabled it to usurp the United States of America and become the world leader in intellectual property rights protection (Property Rights Alliance, 2018). It should be noted that according to the preliminary results of 2019, the three leaders did not change; only Switzerland and New Zealand exchanged places (Property Rights Alliance, 2019).

Finland and New Zealand are those countries that actively use venture capital in various fields of economy and social life (Owen \& Mason, 2019). Kander, Taalbi, Oksanen, Sjöö, and Rilla (2019) note that according to data, Finland catches up with and overtakes Sweden in terms of innovation products in the 1990s. On a per capita basis, Finland remains ahead throughout the entire period. The high performance of Finland is largely due to the growth of innovative activity in only a few sectors but is not limited to only a few companies. In other words, Finland has been achieving its economic progress for decades, overcoming the crises of the 1980s and applying innovations in selected, most progressive areas of the econ- omy since the early 1990s. Obviously, it is more convenient for Finnish business to find economic advantages in applying modern technologies than to fall for breaches of the law, in particular, legislation on the protection of the property rights of a competitor or any other enterprise.

New Zealand's economy is one of the most developed on the planet. The fact is that this country produces natural gas, coal, gold, silver, and other minerals. Kushnirenko and Zarudnaya, experts from the Institute of Economics and Forecasting of NAS of Ukraine, state that state authorities in New Zealand do not interfere with the opening of business. Accordingly, it is easy to implement. They also note that it is easy to register property rights. The country has the largest per capita number of small businesses in the world, with no capital gains tax and no payroll tax. For further innovations in starting a business, experts advise Ukraine to pay attention to New Zealand's experience (Yasynchuk, 2016).

Ukraine tries to study and apply the experience of developed countries, takes steps towards simplification for starting and conducting business, legislative framework (Constitution of Ukraine, Economic Code of Ukraine, special laws and regulations, in particular on investment regulation, corporate relations, etc.) contains rules that define ownership as sacred and provide for its protection by all legal means. However, as has been shown above, the implementation of property rights protection rules, in particular in the economic sphere, is low; according to IPRI, Ukraine has one of the lowest positions in the world. The freedom and ease of registering a business and entering into transactions should not help to attack companies' property rights.

It would be advisable to incorporate rules of different legislative rules into the $\mathrm{CPPCoU}$ for the effective protection of property rights and corporate rights. Some economically developed countries have similar codes and legal issues addressing the attacks on corporate property. Business property owners feel more protected both when doing their business and when selling of their shares in the company. There are several narrow-specialized codified acts in Ukraine. The most recent code is the Bankruptcy Code of Ukraine, which was adopted on October 18, 2018, and entered into 
force on October 21, 2019 (Legislation of Ukraine, 2018, October 18). The proposed Code can be developed and adopted by analogy with it. A single codified act will be convenient to use and effective in comprehensively combating attacks on property and corporate governance boards, as well as the corporate rights of their members (shareholders). Today, the situation is opposite, and public authorities are trying to fine-tune the legislation in various areas, which does not produce the right result. Thus, overcoming the problem of raiding is possible in a set of actions for the development and adoption of legislation aimed at protecting the property rights and interests from the raiders and to its effective implementation by all subjects of corporate relations.

The following measures should be taken to counter raider attacks and increase the level of protection economic entities property in Ukraine.

Developing and adopting a comprehensive $\mathrm{CPPCoU}$ that will be an effective step towards overcoming and combating corporate raiding. The aforementioned regulatory act should state not only the rules of business turnover and the ways of protecting economic entities from attacks on their property, and stipulate the proper liability without reference to the Criminal Code of Ukraine; should define the concept of raiding and describe all known ways of attacks on the property of economic entities. If this legislative act specifies ways of committing raider attacks, then any attack on the property and management of the corporate entity may be qualified as raider and bring the perpetrators (one person or a group of persons) to liability.

The CPPCoU should establish liability for corruption and assistance to raiders on the part of officials. It is necessary to prescribe the possibility of applying sufficiently severe sanctions to the officials who assist raiders.
To create an official state register of raider attacks on the relevant website of state agencies (for example, on the website of the Prosecutor General's Office of Ukraine or the website of the Ministry of Justice of Ukraine), and to determine the functioning of the said register in the CPPCoU. However, all information on the website must be duplicated in English for the convenience of foreign investors. This is necessary in order to give adequate protection to those entities that have already been attacked and to businesses that are potential victims of raiders. It is also necessary to indicate in the said register the persons who carry out raider attacks, as often raiding becomes professional and the clients use groups of persons who have already had an experience of committing attacks on property and management boards of the entities. The introduction of these registers will be useful to law enforcement agencies to verify information on the repeated raider attacks.

Despite the existence of relevant legislation in Ukraine, both foreign and national investors are not protected from attacks on their property. Due to this, they do not want to invest their savings in the activities of companies located in the territory of Ukraine. If Ukraine does not ensure the legal protection of the rights and interests of economic entities and its implementation by all participants in market relations, then further investment in its economy may be lost. As a result, the state will be affected because of the reduced number of jobs and a reduced amount of taxes that come to the budgets from entrepreneurs and the taxation of wages. The country, in turn, will lose its working population, which will go abroad in search of new high-paying jobs, will establish their enterprises abroad, where there are favorable conditions for the developing and doing business, favorable investment legislation and protection of investors from raider attacks. Along with the interests of such individuals, this will ensure the implementation of the economic interests of other states.

\section{CONCLUSION}

The participation of many civil servants in corruption schemes is a consequence of the current socio-economic situation and the level of salaries in the state. Today, steps are being taken to qualitatively change the apparatus of judges and officials in the structure of prosecuting authorities and the Ministry of Internal Affairs. A completely new body in Ukrainian judicial practice, the Supreme Anticorruption 
Court of Ukraine, has been formed and started its work. In general, raiders often cooperate with judges, law enforcement officials, registrars, notaries, prosecutors, and their assistants who make unlawful decisions or fail to adequately protect the rights of attacked businesses. Low salaries are not the main reason for the involvement of officials in cooperation with raiders. The biggest incentive for bureaucrats is their confidence in impunity, which is based on the unprofessional nature of employees of structures that can identify and punish an offender, or the ability to bribe an investigator and (or) a judge. Therefore, an extra reminder of the possibility of liability in conjunction with increasing sanctions will be an effective measure to prevent civil servants from cooperating with raiders. In order to inform Ukrainian and foreign investors and potential counterparties of Ukrainian companies, it would be advisable to launch a state register of raider attacks, which should be bilingual (Ukrainian and English) and contain information on the attempts and cases of raider attacks on property and corporate business rights. Also for further innovations in starting a business, Ukraine must pay attention to New Zealand's and Finland's experience.

\section{REFERENCES}

1. Andrushkiv, B. M., \& Maliuta, L. Ya. (2016). Ekonomichna ta maynova bezpeka biznesu [Economic and property security of business]. Ternopil: FOP Palianytsia V. A. (In Ukrainian). Retrieved from http://elartu.tntu.edu.ua/bitstream/123456789/17973/6/ Ekonomichna_ta_majnova_bezpeka_biznesu.pdf

2. Åslund, A. (2014). The Maidan and Beyond: Oligarchs, Corruption, and European Integration. Journal of Democracy, 25(3), 64-73. https://doi. org/10.1353/jod.2014.0055

3. Demers, C., Giroux, N., \& Chreim, S. (2003). Merger and acquisition announcements as corporate wedding narratives. Journal of Organizational Change Management, 16(2), 223-242. https://doi. org/10.1108/09534810310468170

4. Deutsch, Y., Keil, T., \& Laamanen, T. (2007). Decision Making in Acquisitions: The Effect of Outside Directors' Compensation on Acquisition Patterns. Journal of Management, 33(1), 30-56. https://doi. org/10.1177/0149206306296576

5. Kander, A., Taalbi, J., Oksanen, J., Sjöö, K., \& Rilla, N. (2019). Innovation trends and industrial renewal in Finland and Sweden 1970-2013. Scandinavian Economic History Review, 67(1),
47-70. https://doi.org/10.1080/035 85522.2018 .1516697

6. Köke, J. (2002). Determinants of acquisition and failure: evidence from corporate Germany. Structural Change and Economic Dynamics, 13(4), 457-484. https://doi.org/10.1016/S0954349X(02)00024-3

7. Kuchuk, M. (2018, June 2). Skilky reiderskykh zakhoplen zdiisnyly v Ukraini z 2013-ho roku [How many raider seizures have been carried out in Ukraine since 2013]. The Village. (In Ukrainian). Retrieved from https://www.thevillage.com.ua/village/business/ news/273649-skilki-reyderskihzahoplen-zdiysnili-v-ukrayini-z-2013-go-roku

8. Legislation of Ukraine. (2018, October 18). The Bankruptcy Code of Ukraine (No. 2597-VIII). Retrieved from https://zakon.rada. gov.ua/laws/show/2597-19

9. Legislation of Ukraine. (2019, October 23). The Law of Ukraine "On Amendments to Some Legislative Acts of Ukraine on Protection of Property Rights" (No. 202). Retrieved from https://zakon. rada.gov.ua/laws/show/159-20

10. Lin, C., Officer, M. S., \& Zou, H. (2011). Directors' and officers' liability insurance and acquisition outcomes. Journal of Financial Economics, 102(3), 507-525. https://doi.org/10.1016/j.jfineco.2011.08.004
11. Milyavskyi, M. U., \& Korobka, I. S. (2016). Development of methodological support of internal control how technology to protect corporate enterprises from raiding and other types of hostile takeover. In S. I. Drobyazko (Ed.), Economics, management, law: problems of establishing and transformation (pp. 256-259). Dubai: Al Ghurair Printing and Publishing LLC. (In Russian). Retrieved from https://www.elibrary.ru/item. asp?id=26042385

12. Mokiy, A., Fleychuk, M., \& Datsko, O. (2016). Resursy rozvytku pidpryiemstv v Ukraini: instytutsiini ryzyky [Enterprise Development Resources in Ukraine: Institutional Risks]. Naukovi zapysky Lvivskoho universytetu biznesu ta prava Scientific notes of Lviv University of Business and Law, 16, 37-43. (In Ukrainian)

13. Novak, A. M., \& Zatvarskyi, Ya. (2017). Zapobihannya ryzykam nedruzhnoho pohlynannia $\mathrm{v}$ systemi ekonomichnoi bezpeky pidpryiemstva [Prevention of risks of unfavorable absorption in the economic security of the enterprise]. In VI International Scientific-Practical Conference "Strategic Monitoring and AntiCorruption Audit in the System of Financial and Economic Security of State, Region, Business Entities" (pp. 77-79). (In Ukrainian). 
Retrieved from http://eprints. kname.edu.ua/48494/1/ilovepdf_ com-77-79.pdf

14. Osipian, A. (2018). The Political Economy of Corporate Raiding in Russia (174 p.). London: Routledge. https://doi. org/10.4324/9781351103817

15. Osipian, A. L. (2012). Predatory Raiding in Russia: Institutions and Property Rights After the Crisis. Journal of Economic Issues, 46(2), 469-480. https://doi.org/10.2753/ JEI0021-3624460222

16. Owen, R., \& Mason, C. (2019). Emerging trends in government venture capital policies in smaller peripheral economies: Lessons from Finland, New Zealand, and Estonia. Strategic Change, 28(1), 83-93. https://doi.org/10.1002/ jsc. 2248

17. Parnes, D. (2009). The Corporate Acquisition Policy of Financially Distressed Firms. The Financial Review, 44(4), 603-623. https:// doi.org/10.1111/j.15406288.2009.00232.x

18. Paul, D. L. (2007). Board Composition and Corrective Action: Evidence from Corporate Responses to Bad Acquisition Bids. Journal of Financial and Quantitative Analysis, 42(3), 759-783. https://doi.org/10.1017/ S0022109000004178

19. Property Rights Alliance. (2018). International Property Rights Index 2018. Retrieved from https://www. internationalpropertyrightsindex. org

20. Property Rights Alliance. (2019). International Property Rights Index 2019. Retrieved from https://www. internationalpropertyrightsindex. org/

21. Rochlitz, M. (2014). Corporate raiding and the role of the state in Russia. Post-Soviet Affairs, 30(2-3), 89-114. https://doi.org/10.1080/10 60586X.2013.856573
22. Rochlitz, M. (2017). Violent Pressure on Business and the Size of the Informal Economy: Evidence from Russian Regions. In A. Polese, C. Williams, I. Horodnic, \& P. Bejakovic (Eds.), The Informal Economy in Global Perspective (pp. 173-193). Cham: Palgrave Macmillan. https://doi. org/10.1007/978-3-319-40931$3+10$

23. Rojansky, M. A. (2014). Corporate Raiding in Ukraine: Prevention, Defense, and Policy Reform. Review of Central and East European Law, 39(3-4). 245-289. https://doi.org/10.1163/1573035200000020

24. Shevchuk, I. V. (2017). Sutnist ta osnovni zakhody protydii reiderstvu v korporatyvnomu sektori Ukrainy [The essence and main measures to counteract raiding in the corporate sector of Ukraine]. In III International Scientific-Practical Conference "Stratehichni napriamy sotsialnoekonomichnoho rozvytku derzhavy v umovakh hlobalizatsii" ["Strategic directions for socioeconomic development of the state in conditions of globalization"] (pp. 276-279). (In Ukrainian). Retrieved from http://www. univer.km.ua/doc/Zbirnik_19 09. pdf $\#$ page $=276$

25. Sorokivska, O. A. (2014). Doslidzhennia vyiaviv ekonomichnoho reiderstva $v$ Ukraini ta poshuk shliakhiv yoho podolannia [Investigation of economic raiding in Ukraine and finding ways to overcome it]. Ekonomika, menedzhment, pidpryiemnytstvo - Economy, Management, Entrepreneurship, 26(II), 163-170. (In Ukrainian). Retrieved from http:// nbuv.gov.ua/UJRN/ecmepi_2014_26\%282\%29_21

26. Vashkiv, O. P. (2016). Reiderstvo yak instytutsiina pastka: mekhanizm utvorennia ta poshyrennia [Raiding as an institutional trap: the mechanism of formation and dissemination]. Naukovyi Visnyk Khersonskoho Derzhavnoho Universytetu Scientific Herald of Kherson State University, 19(1), 9-11. (In Ukrainian). Retrieved from http:// www.ej.kherson.ua/journal/economic_19/1/3.pdf

27. Vasylenko, M. (2017). Osoblyvosti reiderstva v konteksti novykh zmin do chynnoho zakonodavstva Ukrainy [Features of raiding in the context of new changes to the current legislation of Ukraine]. Yurydychnyi visnyk - Herald of Law, 1, 58-64. (In Ukrainian). Retrieved from http://www.yurvisnyk.in.ua/v1_2017/12.pdf

28. Vasyliev, O. V., \& Nimkovych, A. I. (2016). Infrastrukturne zabezpechennia nematerialnykh prav aktsioneriv [Infrastructure provision of intangible rights of shareholders]. Ekonomika i suspilstvo - Economy and Society, 7, 716-721. (In Ukrainian). Retrieved from http://www.economyandsociety.in.ua/journal/7_ukr/121.pdf

29. Yastrubetska, L. S. (2017). Osoblyvosti orhanizatsii reiderskykh zakhoplen pidpryiemstv v Ukraini [Features of organization of raider seizures of enterprises in Ukraine]. Ekonomika i suspilstvo - Economy and Society, 9, 1107-1112. (In Ukrainian). Retrieved from http:// www.economyandsociety.in.ua/ journal/9_ukr/189.pdf

30. Yasynchuk, L. (2016). Rai dlia biznesu: Nova Zelandiia stala sensatsieiu u svitovomu ekonomichnomu prostori $[A$ paradise for business: New Zealand has become a sensation in the world's economic space]. (In Ukrainian). Retrieved from http://www.expres.ua/ news/2016/11/10/212175-raybiznesu-nova-zelandiya-stalasensaciyeyu-svitovomu-ekonomichnomu-prostori 